\title{
PENGUATAN NILAI KARAKTER DALAM LAYANAN PENGUASAAN KONTEN UNTUK MENINGKATKAN PRESTASI AKADEMIK MAHASISWA
}

\author{
Martin $^{1}$, Toni Elmansyah ${ }^{2}$, Fety Novianty ${ }^{3}$ \\ ${ }^{1,2}$ Program Studi Bimbingan dan Konseling \\ ${ }^{3}$ Program Studi Pendidikan Pancasila dan Kewarganegaraan \\ Fakultas Ilmu Pendidikan dan Pengetahuan Sosial IKIP PGRI Pontianak \\ Jalan Ampera Nomor 88 Pontianak - 78116, Telepon (0561) 748219 Fax. (0561) 589855 \\ Alamat e-mail: thesikinrani@gmail.com
}

\begin{abstract}
Abstrak
Penelitian ini bertujuan mengetahui peningkatan prestasi akademik mahasiswa setelah diberikan penguatan nilai-nilai karakter dalam layanan penguasaan konten. Metode penelitian yang digunakan yaitu penelitian tindakan dengan bentuk penelitian tindakan bimbingan dan konseling. Teknik pengumpul data yaitu studi dokumenter dan observasi lansung. Alat pengumpul data yang digunakan adalah dokumentasi berupa kartu hasil studi dan panduan observasi. Hasil penelitian menunjukkan bahwa penguatan nilai karakter dalam layanan penguasaan konten dapat meningkatkan prestasi akademik mahasiswa Fakultas Ilmu Pendidikan dan Pengetahuan Sosial Institut Keguruan dan Ilmu Pendidikan Persatuan Guru Republik Indonesia Pontianak.
\end{abstract}

Kata Kunci: penguatan nilai karakter; layanan penguasaan konten; prestasi akademik mahasiswa;

\begin{abstract}
This study aims to determine the increase in student academic achievement after being given reinforcement of character values in content mastery services. The research method used is action research with guidance and counseling action research. Data collection techniques are documentary studies and direct observation. The data collection tool used is documentation in the form of a results card and observation guide. The results showed that strengthening the value of character in content mastery services can improve academic achievement of students of Fakultas Ilmu Pendidikan dan Pengetahuan Sosial Institut Keguruan dan Ilmu Pendidikan Persatuan Guru Republik Indonesia Pontianak.
\end{abstract}

Keywords: strengthening character values; content mastery services; student academic achievement;

\section{PENDAHULUAN}

Dipandang dari problema akademik, beberapa problema yang mungkin dihadapi oleh mahasiswa diantaranya; 1) kesulitan dalam memilih progam studi atau konsentarsi atau pilihan mata kuliah yang sesuai dengan kemampuan waktu yang tersedia, 2) kesulitan dalam mengatur waktu belajar disesuaikan dengan banyaknya tuntutan dan aktivitas perkuliahan, serta kegiatan kemahasiswaan, 3) kesulitan dalam mendapatkan sumber belajar dan buku-buku sumber, 4) kesulitan dalam menyusun makalah, laporan, dan tugas akhir, 5) kesulitan dalam 
mempelajari buku-buku yang berbahasa asing, seperti Bahasa Inggris, 6) kurangnya motivasi dan semangat belajar, 7) adanya kebiasaan yang salah seperti malas,mudah putus asa, tidak ulet atau lainnya, 8) rendahnya rasa ingin tau, 9) tidak disiplin, dan masih banya masalah lainnya.

Beberapa problema akademik yang dipaparkan di atas diantaranya adalah problema yang berkaitan dengan mental atau karakter yang bisa saja terbentuk dalam diri mahasiswasebagai hasil dari pembiasaan dan pendidikan sebelumnya,baik pendidikan dilingkungan keluarga maupun sekolah yang terkadang terfokus pada pengembangan kecerdasan intelektual semata. Effendy, M. 2016 dalam Kemendikbud, (2017: 6) menegaskan, pendidikan kita sesungguhnya melewatkan atau mengabaikan beberapa dimensi penting dalam pendidikan, yaitu olah raga (kinestetik), olah rasa (seni) dan olah hati (etik dan spiritual). Apa yang selama ini kita lakukan baru sebatas olah pikir yang menumbuhkan kecerdasan akademis. Olah pikir ini pun belum mendalam sampai kepada pengembangan berpikir tingkat tinggi, melainkan baru pada pengembangan olah pikir tingkat rendah. Persoalan ini perlu diatasi dengan sinergi berkelanjutan antara pemerintah, sekolah, orang tua, dan masyarakat melalui penguatan pendidikan karakter untuk mewujudkan Indonesia yang bermartabat, berbudaya, dan berkarakter.

Pelaksanaan pendidikan karakter akan membentuk karakter baik bagi sipembelajar. Karakter yang baik, akan mampu mewujudkan keberhasilan sipembelajar. Baik keberhasilan dalam prestasi belajar maupun keberhasilan positif dalam hal lainnya. Maka dari itu nilai-nilai karakter yang dipahami, dihayati, dan diaplikasikan dalam bentuk tingkah laku dapat mendukung sipembelajar (mahasiswa) mencapai prestasi akademik yang baik. Sebagaimana disampaikan di atas, bahwa salah satu nilai karakter adalah disiplin. Disiplin merupakan salah satu nilai yang mempunyai peranan penting terhadap prestasi akademik mahasiswa. Hasil penelitian Saputro (2012) terhadap mahasiswa menunjukkan bahwa terdapat pegaruh yang signifikan antara disiplin belajardan lingkungan teman sebaya terhadap prestasi akademik mahasiswa. 
Secara psikologis, keberhasilan seseorang termasuklah prestasi akademik bukan semata, dikarenakan Kecerdasan Intelektual (IQ), terdapat faktor lain seperti Kecerdasan Spritual (SQ), Kecerdasan Emosional (EQ), Kecerdasan Interpersonal, maupun nilai-nilai yang dianut (seperti nilai karakter religius, kemandirian, usaha keras , kedisiplinan dll). Aunurrahman (2012: 85) menyatakan, beberapa bentuk kualitas emosional yang dinilai peting bagi keberhasilan (salah satunya keberhasilan belajar) yaitu; 1) empati, 2) mengungkapkan dan memahami perasaaan, 3) mengendalikan amarah, 4) kemandirian, 5) kemampuan menyesuaikan diri, 6) disukai, 7) kemampuan memecahkan masalah antar pribadi, 8) ketekunan, 9) kesetiakawanan, 10) keramahan, dan 11) sikap hormat.

Kesemua paparan tersebut merupakan bagian nilai karakter, maka dari itu semakin jelas bahwa beberapa nilai karakter mempunyai peranan penting dalam upaya meningkatkan prestasi akademik mahasiswa. Semakin kuat dan baik karakter yang dimiliki seseorang maka semakin berpeluang untuk memahami dan mengoptimalkan potensi yang dimilikinya.

Bimbingan dan konseling di Perguruan Tinggi merupakan usaha membantu mahasiswa untuk mengembangkan dirinya dan mengatasi problemaproblema akademik serta problema sosial-pribadi yang berpengaruh terhadap prestasi akademik mereka. Bimbingan tersebut meliputi layanan bimbingan akademik, pribadi-sosial dan karier yang biasanya diberikan oleh Dosen Bimbingan dan Konseling dan atau Dosen Pembimbingan Akademik (PA) pada tingkat jurusan atau program studi.

Salah satu layanan bimbingan dan konseling yang dapat diberikan kepada mahasiswa dalam mengembangkan nilai karakter adalah layanan penguasaan konten. Layanan penguasaan konten dalam bimbingan dan konseling merupakan bantuan yang diberikan kepada individu agar memiliki konten-konten tertentu. Konten yang dimaksud berupa pemahaman, pengetahuan, nilai-nilai yang diwujudkan dalam bentuk keterampilan, kebiasaan atau perilaku yang berguna bagi diri sendiri dan dalam interaksi dengan lingkungan. Layanan penguasaan konten digunakan untuk membantu peserta didik menguasai konten-konten 
tertentu, terutama konten-konten yang berisi kompetensi dan atau kebiasaan yang berguna dalam kehidupan di sekolah, keluarga, dan masyarakat (P4TK Penjas dan BK Kemendikbud, 2008: 9). Layanan penguasaan konten diberikan dengan memberikan pemahaman kepada penerima layanan tentang nilai-nilai tertentu atau informasi baru yang berguna bagi pengembangan diri penerima layanan.

Problematika mahasiswa di Perguruan Tinggi sering terjadi rendahnya prestasi akademik mahasiswa pada setiap semester, sehingga mempengaruhi terbatasnya jumlah SKS yang dapat diambil pada semester berikutnya. Apabila kondisi ini berlangsung dalam setiap semesternya, tentu akan mempengaruhi ketidaktepataan waktu studi mahasiswa. Banyak faktor yang mempengaruhi, selain faktor Intelegensi Question (IQ), faktor nilai yang dianut (seperti; religius, kesadaran, tanggungjawab, usaha keras dan nilai lainnya) juga bagian penting yang mempengaruhi prestasi akademik mahasiswa.

Berdasarkan wawancara yang dilakukan dengan beberapa Dosen, Sekretaris dan Ketua Program Studi di lingkungan Fakultas F. IPPS, pada setiap semester selalu ada mahasiswa yang IPS-nya di bawah 3.00. Beberapa kasus terdapat mahasiswa yang tidak dapat mengambil seluruah matakuliah yang disediakan pada setiap semester. Sementara dalam proses perkuliahan masih banyak ditemukan mahasiswa yang mengindikasikan kuranyanya internalisasi nilai-nilai karakter dalam sikap. Kondisi ini, seperi masih ditemukan mahasiswa yang kurang disiplin (seperti telat dan mengumpulkan tugas), tidak jujur (seperti memalsukan tandatangan dosen, menyontek saat UAS), kurang gemar membaca (seperti mengerjakan tugas menyadur dan mengcopy dari situs internel), dan kurang usaha keras (seperti mudah putus asa dan tidak ulet dalam mengatasi masalah belajar).

Oleh karena itu, peneliti merasa perlu adanya penguatan nilai-nilai karakter dalam layanan bimbingan dan konseling yang disusun secara rinci. Upaya tersebut akan peneliti rumuskan dalam penelitian "Penguatan Nilai-nilai Karakter dalam Layanan Penguasaan Konten untuk Meningkatkan Prestasi Akademik Mahasiswa Semester II Fakultas IPPS IKIP PGRI Pontianak”. 
Alasan dipilihnya pelaksanaan layanan penguasaan konten yang mengintegrasikan beberapa nilai karakter untuk meningkatkan prestasi akademik mahasiswa, menurut peneliti mempunyai beberapa kelebihan; 1) penguatan nilainilai karakter dalam pelaksanaan layanan penguasaan konten sangat memperhatikan prinsipPenguatan Pendidikan Karakter (PPK) yang salah satunya adalah prinsip holistik, pengembangannya menyeluruh (olah pikir, rasa, olah hati dan raga) sebagaimana dalam panduan Kemendikbud.Prinsip ini sejalah dengan hakikat dari pelaksanaan layanan penguasan konten yaitu seperangkat pengetahuan, nilai-nilai, keterampilan dan perilaku dirumuskan secara menyeluruh, dan 2) kecenderungan sikap mahasiswa terhadap pelaksanaan pendidikan karakter "baik", yang diikuti dengan baiknya karakter mahasiswa, seperti; meningkatnya ketaatan terhadap tata tertib kampus, berperilaku sopan, berpakaian rapi, aktif dalam perlombaan dan program kreativitas mahasiswa, (Penelitian Yulianingsih (2015: 245).

\section{METODE}

Metode yang digunakan dalam penelitian ini adalah penelitian tindakan (action research) dengan bentuk Penelitian Tindakan Bimbingan dan Konseling (PTBK). Tadjri (2012: 7) menyatakan "Penelitian Tindakan Bimbingan dan Konseling adalah penelitian kolaboratif yang dilakukan oleh konselor berdasarkan refleksi dengan tujuan untuk memperbaiki mutu layanan bimbingan dan konseling agar kesejahteraan mental siswa meningkat". Penelitian dilaksanakan terdiri dari rangkaian siklus berupa perencanaan, tindakan, observasi, dan refleksi, dengan harapan pelasanaan layanan bimbingan dapat diperbaiki, dan kecerdasan interpersonal maahasiswa.

Subjek dalam penelitian ini adalah mahasiswa semseter II Fakultas IPPS IKIP PGRI Pontianak. Subjek penelitian adalah mahasiswa yang prestasi akademik yang rendah dan beberapa mahasiswa yang prestasi akademik tinggi dengan karakteristik:

a. Mahasiswa yang beberapa mata kuliah mendapatkan nilai $\mathrm{C}$, terutama matakuliah lanjutan atau prasarat. 
b. Mahasiswa yang Indek Prestasi Semester (IPS)-nya di bawah 3.00

c. Beberapa mahasiswa yang IPS-nya di atas 3.00 (sebagai model terjadinya dinamika dalam layanan penguasaan konten).

Teknik dan alat pengumpul data menggunakan teknik studi dokumenter dan observasi langsung dengan alat pengumpulan data berupa dukumentasi dan pedoman observasi.Dokumentasi yang dikumpulkan berupa Kartu Hasil Studi (KHS) untuk mengetahui prestasi akademik mahasiswa. Panduan observasi dibuat untuk mengetahui pelaksanaan penguatan nilai karakter dalam layanan penguasaan konten untuk meningkatkan prestasi akademik mahasiswa.

Analisis data dalam penelitian ini menggunakan pendekatan deskriptif kuantitatif dan kualitatif. Analisis data kuantitatif (data hasil belajar dan pelaksanaan penguatan nilai-nilai karakter dalam layanan penguasaan konten) dianalisis menggunakan pendekatan deskriptif komparatif, yaitu dengan membandingkan nilai tes awal dengan nilai tes setelah diberikan tindakan (siklus) dan membandingkan nilai observasi pelaksanaan tindakan siklus I dengan siklus II.

Teknik analisis data kuantitatif yang digunakan untuk membandingkan prestasi akademik mahasiswa sebelum dan sesudah diberikan tindakan serta untuk mengetahui keberhasilan tindakan antara siklus satu dan dua menggunakan teknik persentase dangan rumus:

$$
\mathrm{X} \%=\frac{n}{N} x 100 \%
$$

\section{Keterangan:}

$\mathrm{X} \%=$ Hasil persentase

$\mathrm{n} \quad=$ Jumlah skor aktual

$\mathrm{N} \quad=$ Jumlah skor ideal ( Moh. Ali, 2009: 18)

Adapun tolok ukur yang digunakan dalam perhitungan tersebut adalah (a) baik, (b) cukup baik, dan (c) kurang baik. Penentuan tolok ukur yang digunakan dalam penelitian ini khususnya tolok ukur variabel tindakan berpedoman padarentang skor pada masing-masing kategori sebagaimana pada tabel 1 . 
Tabel 1. Tolok Ukur Penilaian Skala Psikologis

\begin{tabular}{|c|c|c|}
\hline Kategori & Rentang Skor & \% (Persentase) \\
\hline Baik & $30-36$ & $77.34-100 \%$ \\
Cukup Baik & $24-29$ & $54.68-.77 .33 \%$ \\
Kurang Baik & $18-23$ & $33.33-54.67 \%$ \\
\hline
\end{tabular}

Sedangan teknik analisis data kualitatif dilakukan untuk menganalisis terjadinya peningkatan atau tidak pelaksanaan penguatan nilai-nilai karakter dalam layanan penguasaan konten terhadap prestasi akademik mahasiswa. Beberapa prinsip yang dijadikan pegangan dalam menganalisis data kualitatif agar dapat dipertanggungjawabkan keabsahannya diantaranya mempertimbangkangkan situasiapa adanya tanpa rekayasa. Samsudi (2009: 119) menyarankan beberapa prinsip yang harus dipenuhi apabila ingin menganalisis data kualitatif, yaitu:

a. naturalistik: yakni, analisis data harus mendasarkan situasi nyata yang berubah secara alamiah, terbuka dan tidak ada rekayasa pengontrolan variabel.

b. analisis induktif: yakni dengan mendasarkan prosedur berfikir induksi, dimensi, hubungan penting dan asli, yang diungkap melalui pertanyaan terbuka.

c. holistik: artinya totalitas fenomena harus dipahami oleh peneliti dan tidak dilihat secara parsial.

\section{HASIL DAN PEMBAHASAN}

Hasil prestasi akademik sasaran penguatan nilai-nilai karakter dalam layanan penguasaan konten dipaparkan sebagimana Tabel 2, 3, 4 dan 5 berikut:

\section{Tabel 2. Prestasi Akademik Mahasiswa Semester II Program Studi Bimbingan Konseling}

\begin{tabular}{|c|l|c|c|c|c|}
\hline No & Nama & NIM & IPK S.I & IPK S.II & Ket \\
\hline 1. & UP & $\mathbf{1 1 1 7 1 0 0 . .}$ & $\mathbf{3 . 1 9}$ & $\mathbf{2 . 8 6}$ & \\
\hline 2. & PI & $1117100 .$. & 2.28 & 2.67 & \\
\hline 3. & AN & $1117100 .$. & 2.62 & 2.00 & \\
\hline 4. & MA & $1117100 .$. & 2.71 & 2.90 & \\
\hline 5. & RI & $1117100 .$. & 2.71 & 2.86 & \\
\hline 6. & WY & $1117100 .$. & 2.76 & 0.62 & Tidak mengikuti \\
\hline
\end{tabular}




\begin{tabular}{|c|l|l|l|l|l|}
\hline & & & & & kegiatan \\
\hline 7. & LS & $1117100 .$. & 2.81 & 3.00 & \\
\hline 8. & GN & $1117100 .$. & 2.90 & 3.19 & \\
\hline 9. & AI & $1117100 .$. & 2.90 & 3.10 & \\
\hline 11. & MD & $1117100 .$. & 2.90 & 3.00 & \\
\hline 12. & JI & $1117100 .$. & 2.90 & 2.90 & \\
\hline
\end{tabular}

Tabel 3. Prestasi Akademik Mahasiswa Semester II Program Studi Pendidikan Kewarganegaraan

\begin{tabular}{|c|l|c|c|c|c|}
\hline No & Nama & NIM & IPK S.I & IPK. S.II & Ket \\
\hline $\mathbf{1 .}$ & AG & $\mathbf{1 2 1 7 1 0 0 . .}$ & $\mathbf{3 . 9 0}$ & $\mathbf{3 . 7 1}$ & \\
\hline 2. & EK & $1217100 .$. & 2.43 & 1.76 & \\
\hline 3 & HE & $1217100 .$. & 3.10 & 3.33 & \\
\hline 4 & RA & $1217100 .$. & 2.90 & 3.00 & \\
\hline 5 & UM & $1217100 .$. & 3.00 & 3.71 & \\
\hline
\end{tabular}

Tabel 4. Prestasi Akademik Mahasiswa Semester II Program Studi Pendidikan Sejarah

\begin{tabular}{|c|l|c|c|c|c|}
\hline No & Nama & NIM & IPK S.I & IPK S.II & Ket \\
\hline $\mathbf{1 .}$ & RU & $\mathbf{1 3 1 7 1 0 0 . .}$ & $\mathbf{4 . 0 0}$ & $\mathbf{3 . 7 1}$ & $\begin{array}{l}\text { Tidak Mengikuti } \\
\text { Kegiatan }\end{array}$ \\
\hline 2. & RS & $1317100 .$. & 3.10 & 3.24 & \\
\hline 3. & MO & $1317100 .$. & 3.19 & 3.24 & \\
\hline 4. & HS & $1317100 .$. & 3.24 & 3.38 & \\
\hline 5. & BB & $1317100 .$. & 3.24 & 3.10 & \\
\hline 6. & RO & $1317100 .$. & 3.00 & 1.67 & \\
\hline 7. & LU & $1317100 .$. & 3.05 & 2.48 & \\
\hline 8. & EA & $1317100 .$. & 3.14 & 3.43 & \\
\hline 9. & ML & $1317100 .$. & 3.14 & 3.10 & \\
\hline 10. & UT & $1317100 .$. & 3.24 & 2.95 & \\
\hline
\end{tabular}

Tabel 4. Prestasi Akademik Mahasiswa Semester II Program Studi Pendidikan Geografi

\begin{tabular}{|c|l|c|c|c|c|}
\hline No & \multicolumn{1}{|c|}{ Nama } & NIM & IPK S.I & IPK S.II & Ket \\
\hline 1. & SO & $\mathbf{1 4 1 7 1 0 0 . .}$ & $\mathbf{3 . 9 0}$ & $\mathbf{3 . 6 2}$ & \\
\hline 2. & EO & $1417100 .$. & 2.52 & 1.52 & $\begin{array}{l}\text { Tidak mengikuti } \\
\text { kegiatan }\end{array}$ \\
\hline 3. & JL & $1417100 .$. & 2.76 & 2.81 & \\
\hline 4. & BI & $1417100 .$. & 2.86 & - & $\begin{array}{l}\text { Tidak mengikuti } \\
\text { kegiatan }\end{array}$ \\
\hline 5. & YA & $1417100 .$. & 2.86 & 2.52 & \\
\hline 6. & YL & $1417100 .$. & 2.90 & 3.00 & \\
\hline
\end{tabular}




\begin{tabular}{|c|l|c|c|c|l|}
\hline 7. & AM & $1417100 .$. & 2.95 & 3.00 & \\
\hline 8. & LI & $1417100 .$. & 2.95 & 3.29 & \\
\hline 9. & SY & $1417100 .$. & 1.90 & - & $\begin{array}{l}\text { Tidak mengikuti } \\
\text { kegiatan }\end{array}$ \\
\hline 10. & KO & $1417100 .$. & 2.90 & - & $\begin{array}{l}\text { Tidak mengikuti } \\
\text { kegiatan }\end{array}$ \\
\hline 11. & JI & $1417100 .$. & 2.90 & 2.95 & \\
\hline 12. & FX & $1417100 .$. & 2.95 & 3.05 & \\
\hline 13. & AH & $1417100 .$. & 3.00 & 3.00 & \\
\hline
\end{tabular}

Prestasi akademik mahasiswa semester I program studi Bimbigan dan Konseling, Pendidikan Kewarganegaraan, Pendidikan Sejarah dan Pendidikan Geografi Fakultas Ilmu Pendidikan dan Pengetahuan Sosial Semester (F.IPPS) dalam penelitian ini diketahui dari Kartu Hasil Studi (KHS) yang telah diperloleh selama satu semester. Berdasarkan KHS tersebut, mahasiswa didata terkait Indek Prestasi Semester (IPS) yang mencapai di atas dan di bawah 3.00. Identifikasi masalah penelitian dipilih bagi mahasiswa yang IPS dibawah 3.00. Mahasiswa yang IPS-nya di bawah 3.00 inilah yang menjadi prioritas bantuan untuk diberikan layanan penguasaan konten. Namun untuk kebutuhan keterwakilan setiap program studi terdapat beberapa mahasiswa yang IPS-nya di atas 3.00 dengan catatan IPS tersebut merupakan IPS yang rendah diantara teman-temannya. Sedangkan untuk dinamika kegiatan dan motivasi, maka dipilih perwakilan IPS tertinggi sebagai model mahasiswa berprestasi masing-masing program studi.

Jumlah mahasiswa pada empat program studi yang terdata berjumlah 165 mahasiswa. Dari mahasiswa tersebut yang menjadi prioritas layanan sebanyak 44 mahasiswa (26.67\%), termasuk 4 mahasiswa prioritas yang menjadi model siswa yang berprestasi. Mahasiswa yang menjadi prioritas tersebut yang nantinya akan mengikuti kegiatan penguatan nilai-nilai karakter dalam layanan penguasaan konten untuk meningkatkan prestasi akademik mahasiswa.

Berdasarkan penentuan prioritas sasaran layanan, maka selanjutnya direncanakanlah bantuan untuk meningkatkan prestasi akademik mahasiswa yaitu melalui layanan penguasaan konten. Layanan penguasaan konten yang diberikan terintegrasi dengan penguatan nilai-nilai karakter. Tujuan layanan penguasan konten yang diberikan pada hakikatnya untuk mengembangkan konten-konten 
tertentu yang dimiliki oleh mahasiswa. Konten yang ingin dikembangkan berupa pengetahuan, nilai, sikap dan keterampilan yang diperlukan dalam rangka meningkatkan prestasi akademik mereka.

Pelaksanaan kegiatan penguatan nilai-nilai karakter dalam layanan penguasaan konten untuk menigkatkan prestasi akademik mahasiswa dilakukan melalui siklus tindakan. Siklus tindakan yang dilakukan terdiri dari 2 siklus. Masing-masing siklus terdiri dari dua pertemuan. Materi yang diberikan terdiri dari 4 materi yaitu; 1) Sukses Belajar Diperguruan Tinggi. 2) Nilai-Nilai Karakter yang Dibutuhkan dalam Belajar 3) Masalah-masalah studi diperguruan tinggi dan Kiat Mengatasinya. 4) Internalisasi Nilai-Nilai Karakter yang Diperlukan dalam Belajar. Dalam rangka memperkuat nilai-nilai karakter yang dibutuhkan dalam belajar, pelaksanaan layanan penguasaan konten berupaya menciptakan pembelajaran berpedoman pada prinsip Penguatan Pendidikan Karakter (PPK), yaitu pembelajaran yang melibatkan aktivitas (oleh raga), intelektual (olah pikir), estetika (olah rasa) dan spiritual (olah hati).

Pada siklus I pertemuan pertama dan kedua secara umum kegiatan layanan berjalan lancar. Berdasarkana hasil observasi, siklus I pertemuan pertama memperoleh skor aktual sebesar 26 dari skor aktual sebesar 36 dengan persentase sebesar 72.22\% termasuk kategori "Cukup Baik". Sedangkan pelaksanaan penguatan nilai-nilai karakter dalam layanan penguasaan konten siklus I pertemuan kedua skor aktual sebesar 29 dari skor aktual sebesar 36 dengan persentase sebesar $80.56 \%$ termasuk kategori "Baik".

Beberapa keterbatasan penguatan nilai-nilai karakter dalam layanan penguasaan konten yang telah dilakukan pada siklus I pertemuan pertama dan kedua diantaranya; 1) layanan yang diberikan kurang melibatkan aktivitas mengembangkan aktivitas (olah raga), intelektual (olah pikir), estetika (olah rasa), etika dan spiritual (olah hati) secara simultan. 2) Keluasan cakupan materi dengan contoh real belajar mahasiswa belum maksimal, dan 3) Materi yang disampaikan kurang dihubungkan dengan internalisasi nilai-nilai karakter dalam belajar.

Keterbatasan siklus I pertemuan pertama dan kedua tersebut, menjadi pertimbangan untuk melakukan perbaikan disiklus kedua. Berdasarkan hasil 
observasi pelaskanaan layanan siklus II pertemuan pertama memperoleh skor aktual sebesar 29 dari skor aktual sebesar 36 dengan persentase sebesar $80.56 \%$ termasuk kategori "Baik”. Sedangkan pelaksanaan penguatan nilai-nilai karakter dalam layanan penguasaan konten siklus II pertemuan kedua skor aktual sebesar 28 dari skor aktual sebesar 36 dengan persentase sebesar $77.78 \%$ termasuk kategori "Baik".

Pada akhir kegiatan baik siklus I maupun siklus II, selama pertemuan maupun setelah pertemuan (Pekerjaan Rumah) mahasiswa diberikan tugas dalam rangka mengembangkan aktivitas (olah raga), intelektual (olah pikir), estetika (olah rasa) dan spiritual (olah hati). Beberapa tugas yang diberikan diantaranya; a) mengekplorasi masalah atau keterbatasan nilai karakter yang diperlukan dalam belajar (cth, kurang disiplin dalam belajar, kurangnya usaha keras dalam belajar, tidak bertanggungjawab dalam belajar dll), b) mengamati, menghayati dan mengesplorasi model mahasiswa berprestasi, c) mencari harta karun (tugas kelompok memilih dan memilah beberapa indicator yang telah disiapkan dikaitkan dengan nilai karakter tertentu yang dibutuhkan dalam belajar yang selanjutnya dipresentasikan atau dishare kepada kelompok lain), d) mahasiswa diminta untuk menuliskan target IPS pada semester dua, selanjutnya mahasiswa diarahkan untuk berkomitmen terhadap target yang telah dituliskan, dan d) "Bola Diri”. Tugas ini merupakan tugas untuk mengenal dan mengontrol diri terkait keterbatasan nilai karakter yang tidak atau kurang diamalkan. Selajutnya dari keterbatasan tersebut mahasiswa mengevaluasi dan memperbaiki diri melalui upaya-upaya yang dilakukan untuk mengatasi keterbatasan tersebut. Mahasiswa diminta selama satu bulan mengevalusi diri dan memperbaiki diri, selanjutnya dicatat dan dikumpulkan pada pemateri.

Berdasarkan hasil tugas yang telah diberikan, beberapa temuan yang diperoleh sebagaimana kesimpulan berikut:

1. Pada hakikatnya motivasi berprestasi berkembang pada diri mahasiswa, sayangnya banyak mahasiswa yang kurang berkomitmen terhadap target yang telah dituliskan. 
2. Mahasiwa memahami nilai-nilai karakter yang dibutuhkan dalam belajar, namun terdapat beberapa mahasiswa kurang mengamalkan nilai karakter tersebut. Kondisi ini dapat dilihat dari pengamatan pemaparan tugas kelompok dan hasil intropeksi diri yang dilakukan selama satu bulan.

3. Beberapa mahasiswa sudah mencoba untuk memperbaiki diri terkait keterbatasan nilai-nilai karakter kurang diamalkan. Seperti, a) dari yang kurang usaha keras mengejakan tugas kuliah, menjadi berupaya semaksimal mungkin untuk menyelesakan tugas kuliah, b) dari yang kurang percaya diri untuk bertanya dan memberikan komentar menjadi lebih percara diri dan mau mencoba untuk berkomentar.

4. Ditemukan beberapa mahasiswa yang mengaku mengalami kesulitan untuk mengubah diri, karena merasa kondisi tersebut sudah menjadi kebiasaan sejak kecil.

5. Ditemukan beberapa mahasiswa yang mengundurkan diri untuk menjadi lebih baik, hal ini diasumsikan dari; tugas yang telah dibebankan kepada mahasiswa setelah kegiatan tidak dikerjakan/dikumpulkan.

Pada akhir kegiatan untuk mengetahui hasil dari pelaksanan penguatan nilai-nilai karakter, peneliti mendata kembali mahasiswa yang telah mengikuti kegiatan. Dari 44 sasaran layanan, mahasiswa yang mengikuti kegiatan sampai selesai sebanyak 33 mahasswa. Berdasarkan 33 mahasiswa tersebut yang IPS tidak mengalami peningkatan sebanyak 9 mahasiswa (mahasiswa yang menjadi model yang IPS-nya menurun tidak menjadi pertimbangan, mengingat bahwa IPSnya disemester 2 masih di atas 3.50). Data tersebut menunjukkan bahwa $72.72 \%$ mahasiswa menunjukkan peningkatan prestasi akademik setelah mengikuti penguatan nilai-nilai karakter dalam layanan penguasaan konten untuk meningkatkan prestasi akdemik mahasiswa.

Berdasarkan pembahasan yang disampaikan di atas, sebagaimanan pelaksanaan layanan pada siklus I dan siklus II dan hasil prestasi akademik semester II, maka dapat disimpulkan bahwa; "penguatan nilai-nilai karakter dalam layanan penguasaan konten dapat meningkatkan prestasi akademik mahasiswa semester II Fakultas IPPS IKIP PGRI Pontianak. 


\section{SIMPULAN}

Berdasarkan hasil penelitian dan pembasan sebagaimana dipaparkan pada Bab IV hasil penelitian dan pembahasan di atas maka dapat disimpulkan bahwa:

1. Prestasi akademik mahasiswa semester I Fakultas Ilmu Pendidikan Pengetahuan Sosial (F.IPPS) sangat memadai dari 156 mahasiswa yang terdata, hanya 40 mahasiswa yang menjadi prioritas layanan (IPS di bawah 3.00 dan beberapa mahasiswa yang IPS-nya di atas tiga namun terendah dari temantemannya). Jika dilihat perbandingan dari empat program studi, maka program studi Bimbingan dan Konseling yang prestasi akademiknya kurang memadai.

2. Pelaksanaan penguatan nilai-nilai karakter dalam layanan penguasaan konten secara keseluruhan berjalan baik, dapat dilihat dari hasil observasi bahwa siklus I pertemuan pertama tergolong "Cukup Baik" dengan persentase mencapai $72.22 \%$ dan siklus I pertemuan kedua tergolong "Baik" dengan persentase mencapai $80.56 \%$. Sedangkan siklus II pertemuan pertama tergolong "Baik" dengan persentase mencapai $80.56 \%$ dan siklus II pertemuan kedua tergolong "Baik" dengan persentase mencapai 77.78\%. Pelaksanaan layanan penguasaan konten dalam rangka memperkuat nilai-nilai karakter yang dibutuhkan dalam belajar, dapat menciptakan pembelajaran yang melibatkan aktivitas (oleh raga), intelektual (olah pikir), estetika (olah rasa) dan spiritual (olah hati).

3. Pelaksanaan penguatan nilai-nilai karakter dalam layanan penguasaan konten dapat meningkatkan prestasi akademik mahasiswa semester II Fakultas IPPS IKIP PGRI Pontianak.

\section{DAFTAR PUSTAKA}

Kemendikbud. 2017. Konsep dan Pedoman Penguatan Pendidikan Karakter Tingkat SD dan SMP. Jakarta: Kemendikbud.

Tadjri, Imam. 2012. Penelitian Tindakan Bimbingan dan Konseling. Semarang: Widya Karya. 
SOSIAL HORIZON: Jurnal Pendidikan Sosial,

Vol. 6, No. 2, Desember 2019

Samsudi. 2009. Disain Penelitian Pendidikan. Semarang: UNNES Pres

Saputro. 2012. "Pegaruh Disiplin Belajar Terhadap Prestasi Belajar Mahasiswa". Jurnal Pendidikan Akuntansi Indonesia.Vol. 10 No. 1. Hal 78-97.

Yulianingsih. 2015. "Pelaksanaan Pendidikan Karakter di Program Studi Pendidikan Pancasila dan Kewarganegaraan IKIP-PGRI Pontianak". Jurnal Edukasi. Vol. 13. No. 2. Hal: 239-248. 